\title{
GENOMIC SIZE AND PLOIDY LEVEL PATTERNS OF INTERMOUNTAIN WEST LEPIDIUM DETERMINED USING FLOW CYTOMETRY
}

\author{
Robert W. Lichvar ${ }^{1}$
}

\begin{abstract}
AвSTRACT.-The taxonomic status of members of the genus Lepidium in the Intermountain West has been in flux for years. Species concepts and classification of these endemic species from the western United States center on the highly variable L. montanum complex. Until recently, classification treatments that use morphological features in this group have been adequate, but as new species are discovered and more locations reported, the limited number of morphological features available for classification and defining species concepts has led to more uncertainty about taxonomic rankings. As part of a molecular and morphological-based treatment of the group, flow cytometry was used to evaluate 58 collections of Lepidium from the Intermountain West. The ploidy level for 14 species and 11 varieties of Lepidium was surveyed to assess whether ploidy levels affected the interpretation of taxonomic rankings. Of the Lepidium taxa surveyed, $90 \%$ were tetraploid, and several were diploid and hexaploid. Tetraploid occurrences crossed all major species and varieties. No geographic distribution or habitat patterns were associated with ploidy level.
\end{abstract}

Resumen.-Durante años, el estado taxonómico de los miembros del género Lepidium en el área intermontañosa del oeste ha estado en constante cambio. Los conceptos de especie y la clasificación de estas especies endémicas del oeste de los Estados Unidos se enfocan en el complejo L. montanum sumamente variable. Hasta hace poco, los tratamientos de clasificación que utilizan características morfológicas en este grupo han sido adecuados, pero a medida que se descubren nuevas especies y se registran más ubicaciones, el limitado número de características morfológicas disponibles para la clasificación y la definición de los conceptos de especie ha dado lugar a una mayor incertidumbre sobre las clasificaciones taxonómicas. Como parte de una técnica molecular y morfológica del grupo, se utilizó citometría de flujo para evaluar 58 colecciones de Lepidium en el área intermontañosa del oeste. Se realizó un estudio de ploidía en 14 especies y 11 variedades de Lepidium para evaluar si los niveles de ploidía afectaban la interpretación de las clasificaciones taxonómicas. El 90\% de los Lepidium estudiados resultaron ser tetraploides, junto con varios taxa que son diploides y hexaploides. Las ocurrencias tetraploides cruzaron las principales especies y variedades. No se encontraron patrones de distribución o de hábitats geográficos asociados con el nivel de ploidía.

The Brassicaceae are distributed worldwide and consist of 49 tribes, 321 genera, and more than 3660 species (Al-Shehbaz 2012). The use of chromosome numbers for distinguishing differences between genera in the Brassicaceae has been limited (Rollins 1993). Even though chromosome numbers are not taxonomically definitive in Brassicaeae, in some cases the numbers are consistent and not random among different species groups. Rollins $(1955,1979,1993)$ showed that certain species groups within select genera share a similar base number and, in some cases, are associated with groups with specific morphological characteristics. As such, chromosome numbers have supported taxonomic treatments in Brassicaceae between some species (Rollins 1963, Mulligan 1976) but have not been useful in other treatments (Mulligan 1966). As a whole, chromosome counts across the family express frequent occurrence of hybridization, apomixis, and variation in ploidy levels; therefore, chromosome counts may or may not be supportive for taxonomic purposes.

Base chromosome numbers in the family vary from $x=4$ to $x=17$, with more than one-third of the taxa having karyotypes of $x=8$ (Warwick and Al-Shehbaz 2006). Chromosome counts reported by Warwick and Al-Shehbaz (2006) represent 232 of the 321 genera and 1558 of the 3660 species in Brassicaceae. Of the species reported, approximately $37 \%$ are assumed to be polyploids. The percentage estimates may be even higher if diploid species are shown to be paleopolyploids that formed from diploidization (Lysak et al. 2005). Frequent auto- and alloploid events complicate the utility of chromosome numbers even further, along with chromosome reshuffling, fusions, and fissions, which have caused intrageneric numeric

${ }^{1}$ U.S. Army Engineer Research and Development Center, Cold Regions Research and Engineering Laboratory, 72 Lyme Road, Hanover, NH 03755. E-mail: robert.w.lichvar@usace.army.mil 
variation and descending or ascending dysploidy (Lysak et al. 2005). Thus, it is impractical to use the base number for taxonomic interpretation in some genera. In the Brassicaceae, $x=4$ is the lowest base number and is found in 2 unrelated genera-Stenopetalum R. Brown from Australia and Physaria (Nutt.) A. Gray. The highest base number is $x=128$, found in Cardamine (Easterly 1963, Al-Shehbaz 1988). In Lepidium L., the base number is reported as $x=8$, based on 231 counts from 60 species (Warwick and Al-Shehbaz 2006). In the reported counts for Lepidium, 34\% were diploid, $14 \%$ both diploid and polyploid, and 52\% entirely polyploid. Ploidy numbers in the genus are reported as $2 \mathrm{n}=16,24,28,32,40,48,64$, and 80 .

In addition to chromosome counts for supporting the evaluation of ploidy levels, the amount of DNA per nucleus can now be determined using techniques such as flow cytometry (FC; Bennett and Leitch 2005, Doležel and Bartoš 2005). The species of Brassicaceae analyzed with FC to date have shown small nuclear DNA contents and a narrow range of variation (Bennett and Leitch 2005). Genome size can now be superimposed over gene marker-based phylogenies for assessing ancestral DNA content, and FC has provided the ability to trace genome size evolution (Marhold and Lihová 2006). Likewise, DNA content in polyploids of recent origin is expected to be proportional to the ploidy level for the purposes of assessing ploidy level (Bennett et al. 2000). This pattern is reported in several species of Draba L., which include diploids, triploids, tetraploids, hexaploids, and up to 16ploids. This evidence is also supported by molecular markers (Grundt et al. 2005, JordonThaden and Koch 2008).

Polyploidization and hybridization often result in a reticulate pattern of evolution (Marhold and Lihová 2006). These events make reconstruction of evolutionary relationships challenging. Reticulate evolution can be detected by incongruences between phylogenetic trees derived from plastidic $(\mathrm{cp})$ and nuclear (nr) DNA. These incongruences are common in Lepidium between cpDNA and nrDNA ITS (internal transcribed spacers) markers, with common polyploids suggesting allopolyploid speciation in the genus (Mummenhoff et al. 2001, 2004). It has been suggested that increases or decreases in ploidy levels as determined from genome size can be used to indicate the contributions of different parental origins (Wendel et al. 2002, Kellogg and Bennetzen 2004, Leitch and Bennett 2004).

As part of a taxonomic evaluation of native species of Lepidium from the Intermountain West of the United States, a series of research efforts has been undertaken. Recent taxonomic treatments mention that this group needs further molecular studies to clarify species concepts and taxonomic rankings used in the group (Holmgren 2005, Al-Shehbaz and Gaskin 2010). As part of those efforts, this survey reports on ploidy-level studies using flow cytometry methods. The morphological differences that distinguish species and infraspecific taxa within this geographic region are faint but consistent within taxa, implying possible polyploidy, reticulate evolution, or recent hybrid origins. These differences have led to uncertainty about the taxonomic arrangement of the group under review, particularly about what constitutes the species level and how these taxa are related to each other (Hitchcock 1936, 1950, Rollins 1993, Holmgren 2005, Al-Shehbaz and Gaskin 2010).

I used ploidy-level information derived from flow cytometry methods to evaluate whether ploidy-level patterns are helpful in revealing a taxonomic interpretation of Intermountain West Lepidium. One aspect I evaluated was whether ploidy-level patterns are found along geographic ranges associated with landscape or distribution patterns as reported in the literature (Suda et al. 2007, Whittemore and Olson 2011). In this study, 2 main questions addressed the classification of western Lepidium: (1) whether ploidy-level occurrences are associated with geologic, geographic, or ecological settings in the taxonomically problematic Lepidium and (2) whether ploidy levels are associated with certain species groups or certain infraspecific taxa within a species.

\section{Methods}

\section{Plant Material}

Seeds were collected in the field, and plants were grown in a greenhouse to provide green leaf tissue for flow cytometry (FC; Table 1). Seeds were obtained during several extensive field trips throughout the Intermountain West between 2007 and 2009. Search locations of Lepidium of interest were developed using 
location data from herbarium specimens at the Gray Herbarium (GH), the New York Botanical Gardens Virtual Herbarium (Thiers, continuously updated), and the Calflora (2008) herbaria databases online. Other voucher collections, including seeds, were collected by several botanists and shipped to the University of Alaska-Fairbanks (UAF; Table 1).

Seeds were collected from 3-5 individuals per population. Leaf materials were collected from the same individuals for DNA extraction, and voucher specimens were collected from the population for morphological analysis and taxonomic identification.

Geographic patterns of western Lepidium were evaluated by developing distribution maps of data collection points using a geographic information system (GIS). Geographic Universal Transverse Mercator (UTM) coordinates were assigned to all Lepidium voucher specimens and displayed as point locations in ArcGIS 10.0. Based on the species localities, a distribution map was then created and digitized.

Due to uncertainty of the taxonomic status of various rankings, the nomenclature follows several sources. These include Rollins (1993), Hitchcock (1950), Holmgren (2005), and AlShehbaz and Gaskin (2010).

\section{Flow Cytometry}

Live leaf materials were collected from greenhouse-grown Lepidium and kept on ice until processing occurred, generally within 1-3 h. Leaves were placed in a petri dish with equal amounts of leaves from the size standard (Glycine $\max (\mathrm{L}$.) Merr. 'Polanka') maintained in a growth chamber at UAF. Leaf material was chopped in $0.5 \mathrm{~mL}$ of cold chopping buffer using a stainless-steel razor blade. The chopping buffer was modified from Otto (1990) Buffer I by adding $0.5 \% \mathrm{v} / \mathrm{v}$ of Tritonx 100 rather than Tween 20. As the leaves were chopped, an additional $0.5 \mathrm{~mL}$ of cold chopping buffer was added. The samples were filtered through a 30-mm Partec CellTrics (C) filter and centrifuged for $20 \mathrm{~s}$ at $3500 \mathrm{rpm}$. The supernatant was drawn off, and $2 \mathrm{~mL}$ of RNase was added to the pellet. The pellet was resuspended in $0.2 \mathrm{~mL}$ of propidium iodide staining buffer $(28.65 \mathrm{~g}$ dibasic sodium phosphate, $50 \mathrm{mg}$ propidium iodide, $200 \mathrm{~mL}$ deionized water). Samples were stained in the dark for 40 min prior to flow cytometry application.
Flow cytometry (FC) was performed on a BD Bioscience FACSAria flow cytometer (BD Bioscience, San Jose, CA) equipped with FACSDiva Software (BD Bioscience, San Jose, CA). Samples were run until 10,000 nuclei were scored. The DNA content was calculated by comparing the mean peak fluorescence with the internal reference standard, Glycine $\max (\mathrm{L}$.) Merr. 'Polanka' (2C $=2.5 \mathrm{pg}$ DNA; Doležel and Bartoš 2005). Following Doležel and Bartoš (2005), the $2 \mathrm{C}$ value of each sample (somatic cell nuclear content) was estimated as the (sample peak mean/standard peak mean $) \times$ standard $2 \mathrm{C}$ DNA content $(2.5 \mathrm{pg}$ DNA). To verify the range of DNA content, $\mathrm{C}$ values were compared to values reported in the Kew Royal Botanical Gardens DNA Cvalues database (Bennett and Leitch 2012). The $2 \mathrm{C}$ values were used to determine diploids and tetraploids by comparison to reported polyploidy levels from published chromosome counts (Warwick and Al-Shehbaz 2006).

\section{Ploidy Counts Reported in the Literature}

Chromosome counts for 6 of the taxa surveyed here have been previously reported in the literature. These are L. dictyotum A. Gray $(2 \mathrm{n}=32$; Mummenhoff et al. 2004), L. latifolium $\mathrm{L} .(2 \mathrm{n}=24)$, L. lasiocarpum Nutt. ex Torrey \& Gray $(2 \mathrm{n}=32)$, L. integrifolium Nutt. ex Torrey \& Gray var. heterophyllum S. Wats $(2 \mathrm{n}=16)$, L. montanum Nutt. ex Torrey \& Gray var. canescens (Thell.) C.L. Hitchc. $(2 \mathrm{n}=32)$, L. montanum var. jonesii (Rydb.) C.L. Hitchc. $(2 \mathrm{n}=32)$, and L. montanum var. montanum $(2 \mathrm{n}=16$; Warwick and Al-Shehbaz 2006).

\section{RESULTS}

Fifty-eight samples of Lepidium individuals representing 14 species and 11 varieties were surveyed (Table 1). Of these 58 samples, 52 (90\%) were tetraploids. Ploidy levels for the remaining taxa surveyed here are reported for the first time. For the other 3 taxa in this survey that were not tetraploids, the range of ploidy levels included diploid and hexaploid. The taxa having other than a tetraploid count were L. integrifolium (hexaploid), L. montanum var. canescens (diploid), and L. montanum var. cinereum (C.L. Hitchc.) Rollins (syn. var. stellae Welsh \& Reveal) (hexaploid).

The distributions of ploidy levels across species surveyed are shown in Fig. 1. The 


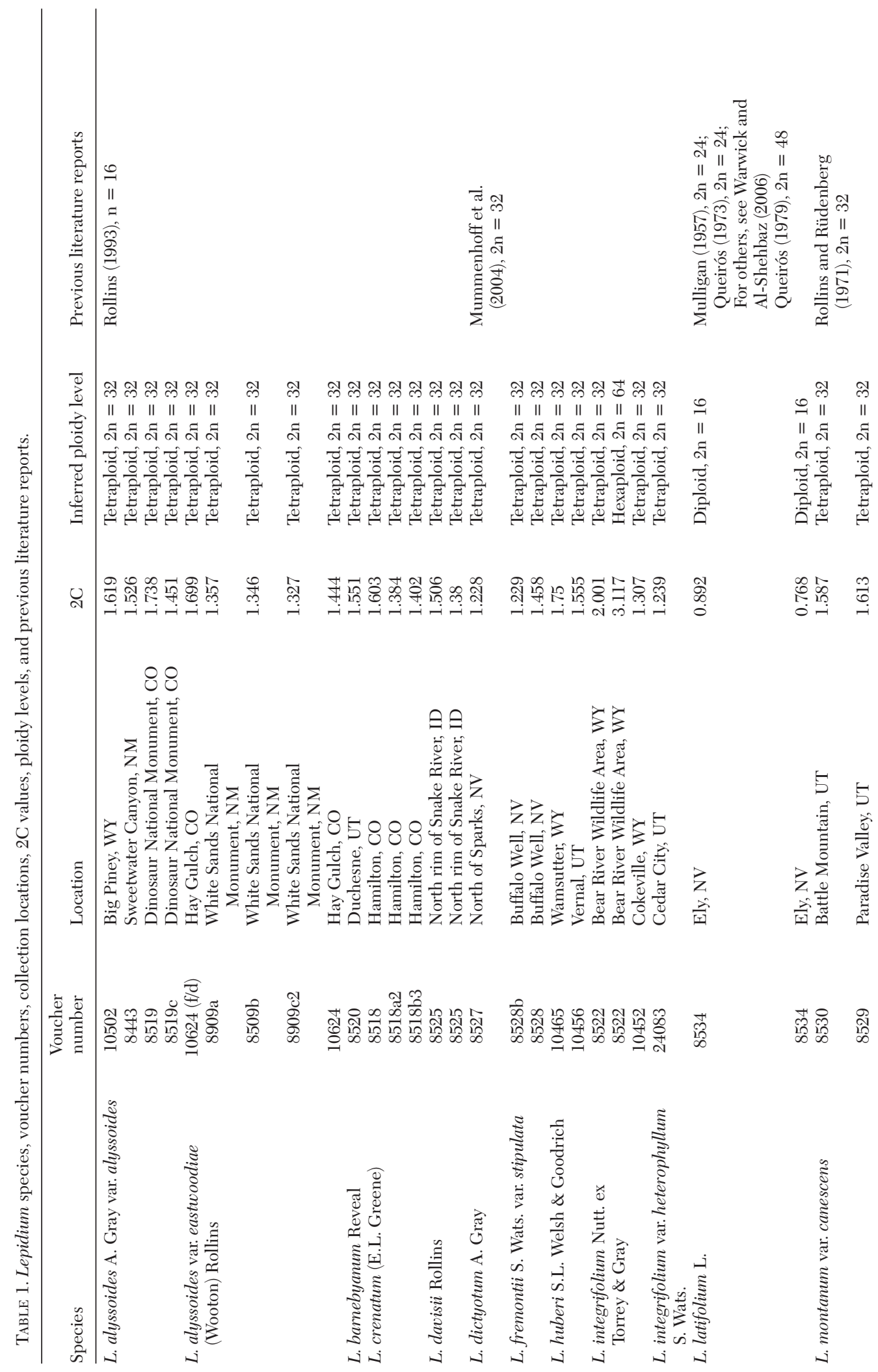




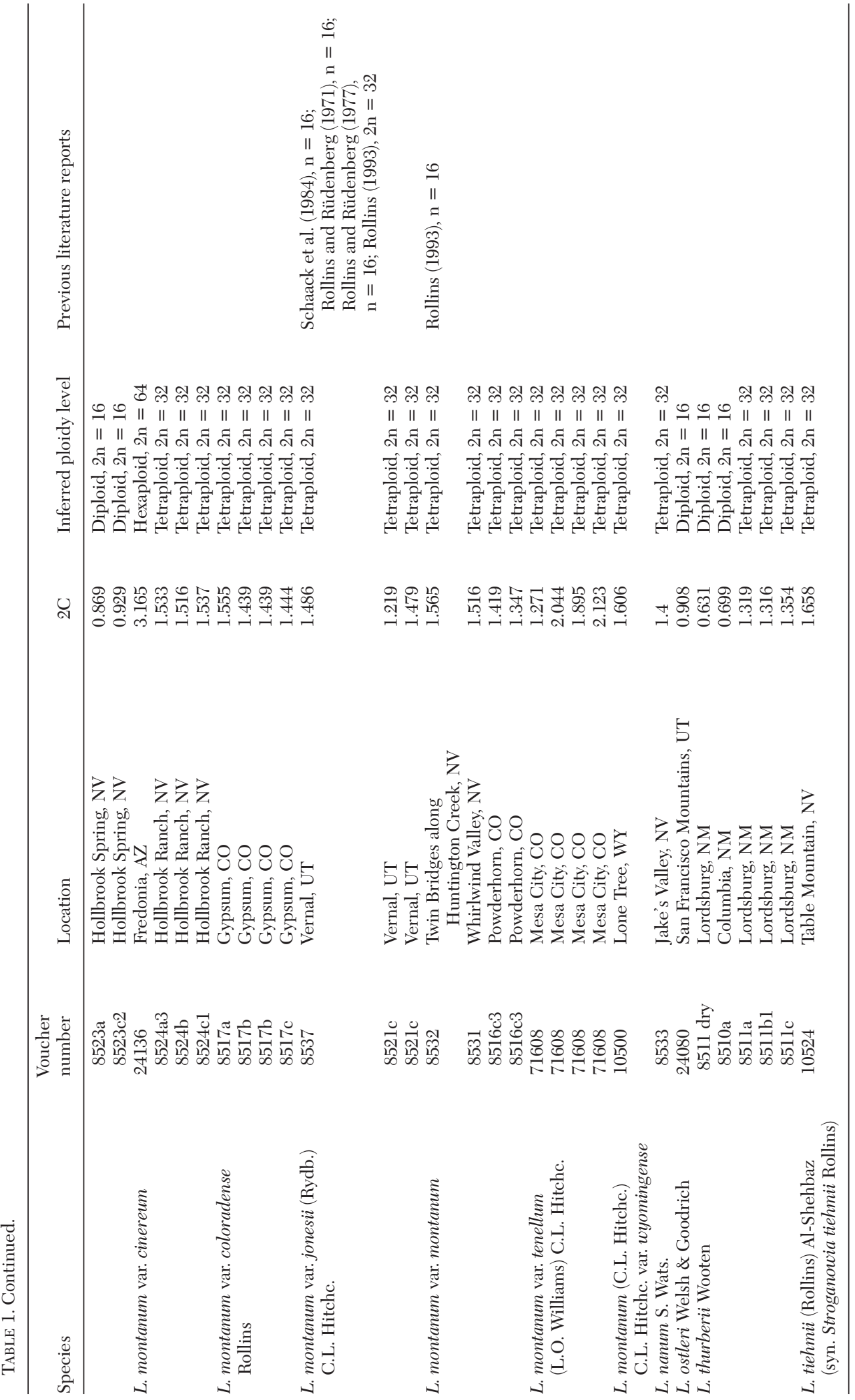




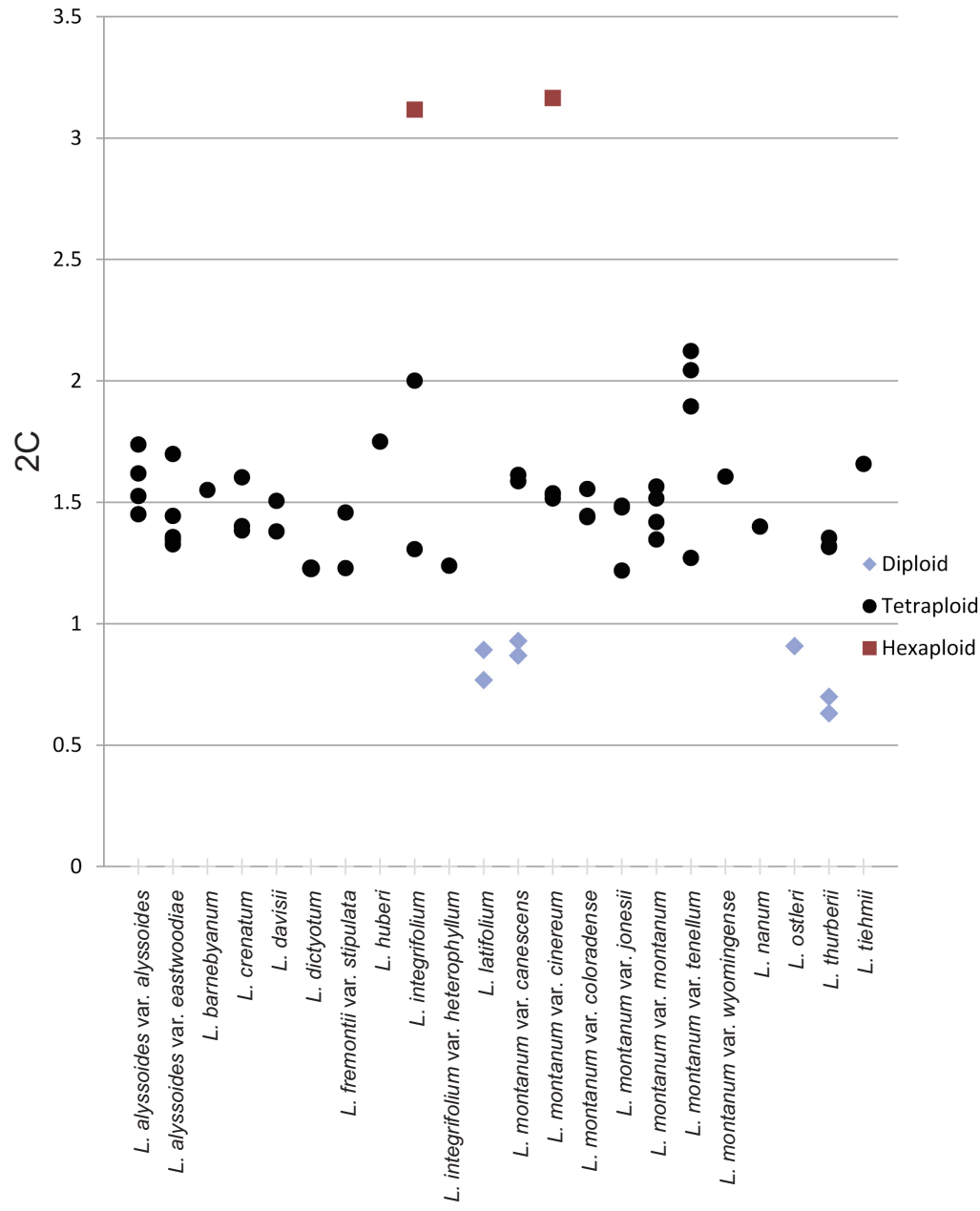

Fig. 1. Distribution of DNA content (2C) ranges across all Lepidium species surveyed.

variation of DNA content (2C value) of the species surveyed shows the overwhelming occurrence of tetraploids throughout the group of 14 species and 11 varieties sampled.

Occurrences of various ploidy levels were scattered across the Intermountain West. Based on the 58 samples surveyed, there are no obvious patterns of ploidy levels associated with landscape type, geographic range, or species complex (Fig. 2). Though there are differences in microhabitat preferences among most of the taxa, ploidy levels were not associated with any particular landscape or habitat feature at the collection sites of the plant material. It appears that ploidy levels, excepting tetraploids, vary randomly and are not influenced by landscape, habitat, or geographic isolation.
Though the amount of DNA may vary between species and within infraspecific taxa, there are typically no differences in ploidy level between a species and its varieties, except for L. montanum var. cinereum, which was found to have both tetraploid and hexaploid counts.

\section{Discussion}

With the high abundance and widespread occurrence of polyploids, especially tetraploids, in the Lepidium surveyed from the Intermountain West, ploidy level does not provide much insight for explaining morphological differences or geographic patterns. However, there are a few noteworthy observations. 


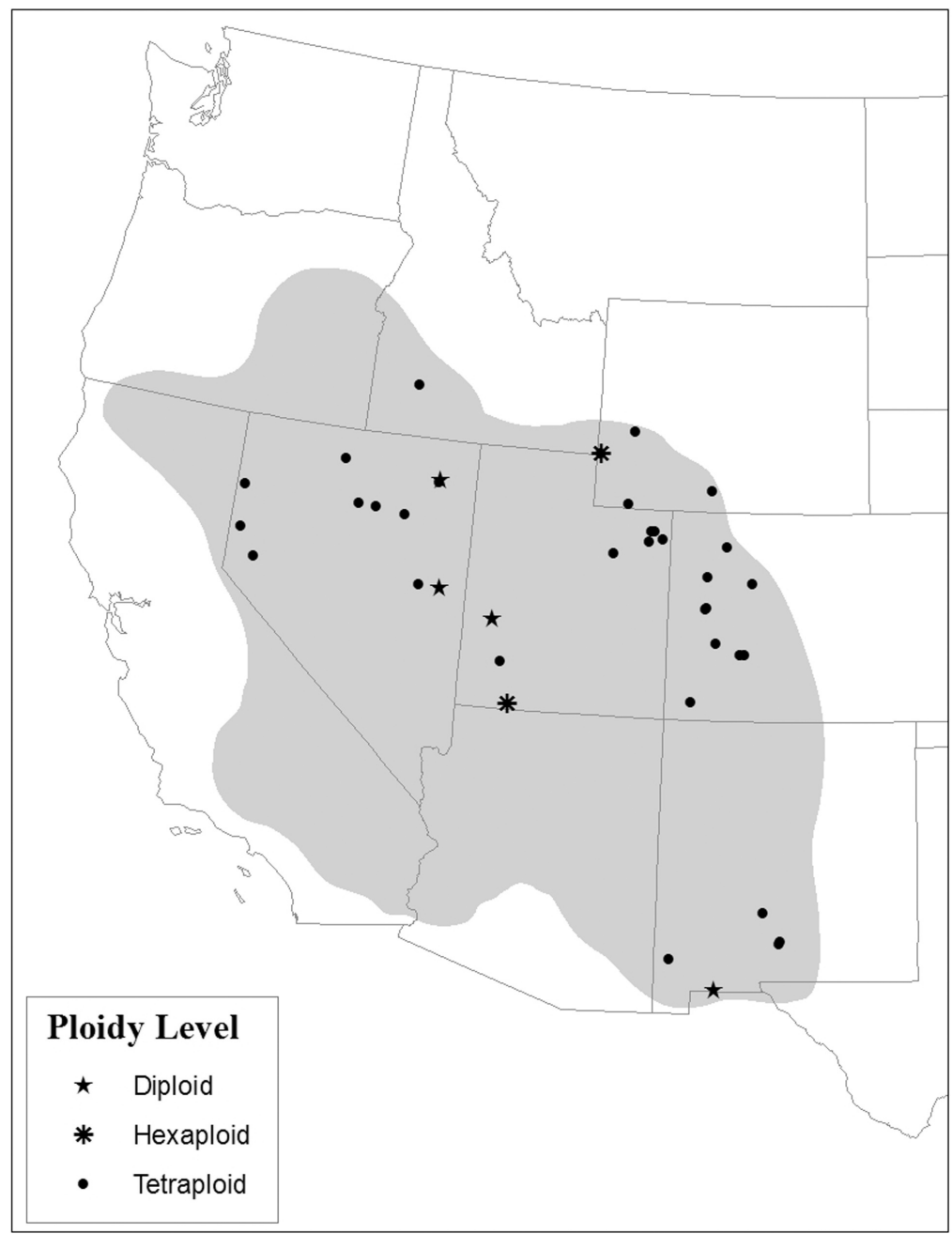

Fig. 2. Distribution of Lepidium with various ploidy levels in the Intermountain West.

Ploidy levels in Lepidium as a whole show that it is not unusual for a single taxon to have more than one ploidy level. Examples of species with more than one ploidy level are L. latifolium (diploid and hexaploid), L. integrifolium (tetraploid, hexaploid, and octoploid), L. montanum var. canescens (diploid and tetraploid), L. montanum var. jonesii (diploid [Warwick and Al-Shehbaz 2006] and tetraploid), and $L$. thurberi (diploid and tetraploid). Of the 7 varieties surveyed in the $L$. montanum complex, only var. cinereum and var. canescens had more than one ploidy level. Variety cinereum is reported as both tetraploid and hexaploid, and var. canescens as both diploid and tetraploid. The hexaploid reported for var. cinereum is from a collection of var. stellae, which has been submerged into the concept of var. cinereum (Al-Shehbaz and Gaskin 2010). However, it is important to note that the results of this survey may not support a significant inference about the lack of correlation between ploidy level and taxonomic, geographic, or habitat group because the number of nontetraploid species was so small.

Historically, the use of chromosome numbers for classification purposes in vascular plant taxonomy has long been limited to supporting or defining the concept of a species. The shape and number of chromosomes are not weighed differently than any other morphological feature for taxonomic purposes 
(Stacy 1980). This is probably a result of the frequent variation in chromosome or ploidy levels. The lack of use of ploidy level to support species concepts is no doubt linked to the fact that over $70 \%$ of angiosperm plants have ploidy level increases in their evolutionary histories (Meyers and Levin 2006). Because multiple ploidy levels are common in most angiosperm groups, it would appear that little distinction among taxa could be obtained from the variability.

Stebbins (1971) proposed that a young polyploid complex would contain many diploids and a few tetraploids. As the complex ages, more species would become polyploids and higher ploidy levels would develop. As time progresses, the ancestor diploids would ultimately die out, resulting in greater difficulty in describing the evolutionary ancestry. Almost all species in this survey were of higher ploidy levels, with $90 \%$ being tetraploids. In addition, the 11 native North American species of Lepidium with reported chromosome counts were $90 \%$ dominated by tetraploids (Warwick and Al-Shehbaz 2006). Using Stebbins's widely accepted concept (Meyers and Levin 2006), the Intermountain West Lepidium complex can be described as an evolutionarily young to moderate-aged species group with a reticulate evolutionary past. The indication of a reticulate evolutionary past has been demonstrated in Lepidium by incongruences in gene trees (Bowman et al. 1999, Mummenhoff et al. 2001, 2004). Bowman et al. (1999) and Mummenhoff et al. (2001, 2004) suggest that most polyploids in Lepidium are allopolyploid. On the basis of previous cpDNA and ITS sequence data, allopolyploidization has been strongly favored to explain gene tree patterns (Mummenhoff et al. 2001, 2004). The influence of a reticulate evolutionary past in the Intermountain West region in this genus, coupled with both high occurrence of polyploidy across all species and highly mobile seeds that are easily transported by avian species to allow for mixing of populations and species (Al-Shehbaz 1986), provides for a diverse array of polyploid genotypes (Soltis and Soltis 1999). This evolutionary background may be setting the challenging stage for adequately classifying these native intermountain species.

In future research on Intermountain West Lepidium, DNA sequences will be analyzed and gene trees developed. Without gene trees, these FC observations and indications of input of different parental DNA stock based on variable sizes of DNA content cannot be conclusively resolved. Likewise, with no association of geographic ploidy levels with geographic ranges or habitats and with variability of DNA content between Lepidium taxa, mere ploidy levels may not be useful for taxonomic purposes. However, ploidy levels do indicate the need for the construction of gene trees to adequately treat these diverse native species of Lepidium in the Intermountain West.

\section{ACKNOWLEDGMENTS}

The quality and content of information reported here would not have been possible without the guidance, comments, and reviews provided by Diana Wolf and Gary Laursen of the University of Alaska and Ihsan Al-Shehbaz of the Missouri Botanical Garden. Funding for this effort was made possible by the U.S. Army Corps of Engineers Engineering and Research Development Center/Cold Regions Research and Engineering Laboratory (ERDC/ CRREL), Hanover, New Hampshire.

\section{Literature Cited}

AL-Shenbaz, I.A. 1986. New wool-alien Cruciferae (Brassicaceae) in eastern North America: Lepidium and Sisymbrium. Rhodora 88:347-356.

1988. The genera of Arabideae (Cruciferae; Brassicaceae) in the southeastern United States. Journal of the Arnold Arboretum 69:85-166.

2012. A generic and tribal synopsis of the Brassicaceae (Cruciferae). Taxon 61:931-954.

Al-Shehbaz, I.A., AND J. Gaskin. 2010. Lepidium L. in Brassicaceae. Pages 226-594 in Flora of North America Editorial Committee, editors, Flora of North America. Volume 7, Magnoliophyta: Salicaceae to Brassicaceae: north of Mexico. Oxford University Press, New York, NY.

Bennett, M.D., P. Bhandol, and I.J. Leitch. 2000. Nuclear DNA amounts in angiosperms and their modern uses-807 new estimates. Annals of Botany (Oxford) 86:859-909.

Bennett, M.D., AND I.J. Leitch. 2005. Nuclear DNA amounts in angiosperms-progress, problems and prospects. Annals of Botany 95:45-90.

. 2012. Plant DNA C-values Database. Release 6.0, December 2012. Available from: http://www.kew .org/cvalues/.

Bowman, J.L., H. Brüggemann, J.-Y. Lee, and K. MumMENHOFF. 1999. Evolutionary changes in floral structure within Lepidium L. (Brassicaceae). International Journal of Plant Sciences 160:917-929.

CALFlora. 2008. Information on California plants for education, research and conservation. The Calflora 
Database, Berkeley, California. Available from: http://www.calflora.org/.

Doležel, J., AND J. Bartoš. 2005. Plant DNA flow cytometry and estimation of nuclear genome size. Annals of Botany 95:99-110.

Easterly, N.W. 1963. Chromosome numbers of some northwestern Ohio Cruciferae. Castanea 28:39-42.

Grundt, H.H., R. Obermayer, and R. Borge. 2005. Ploidal levels in the arctic-alpine polyploid Draba lactea (Brassicaceae) and its low-ploid relatives. Botanical Journal of the Linnean Society 147:333-347.

Hitchсоск, C.L. 1936. The genus Lepidium in the United States. Madroño 3:265-319.

. 1950. On the subspecies of Lepidium montanum. Madroño 10:155-158.

Holmgren, N. 2005. Brassicaceae, the mustard or Crucifer family. Pages $174-418$ in A. Cronquist, N. Holmgren, and P.K. Holmgren, editors, Intermountain flora: vascular plants of the Intermountain West, U.S.A. Volume 2, Part B. New York Botanical Garden, Bronx, NY.

Jordon-Thaden, I., AND M.A. Koch. 2008. Species richness and polyploid patterns in the genus Draba: a first global perspective. Plant Ecology and Diversity 1:255-263.

KellogG, E.A., And J.L. Bennetzen. 2004. The evolution of nuclear genome structure in seed plants. American Journal of Botany 91:1709-1725.

LEITCH, I.J., AND M.D. BENNETT. 2004. Genome downsizing in polyploidy plants. Biological Journal of the Linnean Society 82:651-663.

Lysak, M.A., M.A. Koch, A. Pecinka, and I. Schubert. 2005. Chromosome triplication found across the tribe Brassiceae. Genome Research 15:516-525.

Marhold, K., And J. Lihová. 2006. Polyploidy, hybridization and reticulate evolution: lessons from Brassicaceae. Plant Systematics and Evolution 259:143-174.

Meyers, L.A., AND D.A. Levin. 2006. On the abundance of polyploids in flowering plants. Evolution 60: 1198-1206.

Mulligan, G.A. 1957. Chromosome numbers of Canadian weeds. I. Canadian Journal of Botany 35:779-789.

1966. Chromosome numbers of the family Cruciferae. III. Canadian Journal of Botany 44:309-319. 1976. The genus Draba in Canada and Alaska: key and summary. Canadian Journal of Botany 54: 1386-1393.

Mummenhoff, K., H. Brüggemann, and J.L. Bowman. 2001. Chloroplast DNA phylogeny and biogeography of Lepidium (Brassicaceae). American Journal of Botany 88:2051-2063.

Mummenhoff, K., P. Linder, N. Friesen, J. Bowman, J. LEe, AND A. FranzKe. 2004. Molecular evidence for bicontinental hybridogenous genomic constitution in Lepidium sensu stricto (Brassicaceae) species from Australia and New Zealand. American Journal of Botany 91:254-261.

OтTо, F.J. 1990. DAPI staining of fixed cells for highresolution flow cytometry of nuclear DNA. Pages
105-110 in Z. Darrzynkiewickz and H.A. Crissman, editors, Methods in cell biology. Volume 33. Academic Press, San Diego, CA.

Queirós, M. 1973. Contribuiçao para o conhecimento citotaxonómico das spermatophyta de Portugal. IX. Cruciferae. Boletim da Sociedade Broteriana, Series 2, 47:315-335.

1979. Números cromossómicos para a flora Portuguesa, 16-37. Boletim da Sociedade Broteriana, Series 2, 53:15-28.

Rollins, R.C. 1955. The auriculate-leaved species of Lesquerella (Cruciferae). Rhodora 57:241-264.

1963. The evolution and systematics of Leavenworthia (Cruciferae). Contributions of the Gray Herbarium 192:3-98.

1979. Dithyrea and a related genus (Cruciferae). Publications of the Bussey Institution, Harvard University, Cambridge, MA.

1993. Lepidium. Pages 534-588 in The Cruciferae of continental North America. Stanford University Press, Stanford, CA.

Rollins, R.C., AND L. RüDEnberg. 1971. Chromosome numbers of Cruciferae. II. Contributions of the Gray Herbarium 201:117-133.

1977. Chromosome numbers of Cruciferae. III. Contributions of the Gray Herbarium 207:101-116.

SchaAck, C.G., J.D. Morefield, and W.D. Windham. 1984. Chromosome number reports. LXXXIII (A. Löve, editor). Taxon 33:351-354.

Soltis, D.E., AND P.S. SolTis. 1999. Polyploidy: recurrent formation and genome evolution. Trends in Ecology and Evolution 14:348-352.

Stacy, C. 1980. Plant taxonomy and biosystematics. E. Arnold, London.

Stebbins, G.L. 1971. Chromosomal evolution in higher plants. E. Arnold, London.

Suda, J., H. Weiss-Schneeweiss, A. Tribsch, G. SchneeWEISS, P. TRÁVNIČEK, AND P. SCHÖNSWETTER. 2007. Complex distribution patterns of di-, tetra-, and hexaploid cytotypes in the European high mountain plant Senecio carniolicus (Asteraceae). American Journal of Botany 94:1391-1401.

Thiers, B. [Continuously updated]. Index Herbariorum: a global directory of public herbaria and associated staff. New York Botanical Garden's Virtual Herbarium. Available from: http://sweetgum.nybg.org/ih/.

Warwick, S.I., AND I.A. AL-Shehbaz. 2006. Brassicaceae: chromosome number index and database on CDROM. Plant Systematics and Evolution 259:237-248.

Wendel, J.F., R.C. Cronn, S. Johnston, and H.J. Price. 2002. Feast and famine in plant genomes. Genetica 115:37-47.

Whittemore, A.T., And R.T. Olson. 2011. Ulmus americanus (Ulmaceae) is a ploidy complex. American Journal of Botany 98:754-760.

Received 1 April 2014 Accepted 17 October 2014 